\title{
Proliferation and apoptosis in bovine placentomes during pregnancy and around induced and spontaneous parturition as well as in cows retaining the fetal membranes
}

\author{
A. Boos ${ }^{1}$, V. Janssen ${ }^{2}$ and C. Mülling ${ }^{3}$ \\ ${ }^{1}$ Institute of Veterinary Anatomy, University of Zurich, Winterthurerstrasse 260, CH-8057 Zurich, \\ Switzerland; ${ }^{2}$ Institute of Anatomy, School of Veterinary Medicine Hannover, Bischofsholer Damm 15, \\ D-30173 Hannover, Germany; and ${ }^{3}$ Institute of Veterinary Anatomy, Histology and Embryology, Free \\ University of Berlin, Koserstrasse 20, D-14195 Berlin, Germany
}

Placental growth can be achieved by either cellular proliferation or hypertrophy. Tissue regeneration and the nutrition of the fetus via embryotrophe require high rates of cellular turnover and the so-called pre-term 'maturation' of the placenta is correlated with a reduction of maternal crypt epithelial cells. Placentomes of 45 pregnant cows were collected from an abattoir to assess the role of proliferation and apoptosis in placental physiology and pathology. Placentomes were also taken from five cows undergoing premature Caesarean section and from ten naturally calving cows immediately after the expulsion of the fetus. Five of these animals had not released the fetal membranes after $12 \mathrm{~h}$. Tissue sections of placentome were assessed for the Ki-67 protein; the TUNEL procedure was performed and verified by transmission electron microscopy. The maternal crypt epithelium and the fetal chorionic epithelium had a higher percentage of Ki-67-positive cells than the stroma. The percentage of Ki-67-positive cells increased significantly during pregnancy in fetal chorionic epithelium and was significantly decreased in fetal chorionic epithelium and maternal crypt epithelium after the expulsion of the fetus in comparison with tissue from month 9 of pregnancy. The number of apoptotic cells increased significantly during pregnancy in maternal crypt epithelium, maternal stroma and fetal chorionic epithelium as detected in slaughtered animals. Significantly more apoptotic fetal chorionic epithelial cells were found in animals retaining their fetal membranes in comparison with prepartum cattle during month 9 of pregnancy, at premature section and in animals releasing the fetal membranes completely. The results strongly indicate that bovine placentomes have cell type-specific rates of cellular turnover reflecting tissue growth, embryotrophe and placental maturation. Retention of fetal membranes is characterized by a large number of fetal chorionic epithelial cells undergoing apoptosis immediately after the expulsion of the fetus. This finding indicates that incomplete maturation of placentomes plays an important role in fetal membrane retention and that massive apoptosis after the expulsion of the fetus should be the consequence of diminished blood supply to the uterus, as verified in a recent study.

\section{Introduction}

Retention of fetal membranes is a major problem in bovine gynaecology and obstetrics often leading to subsequent infertility and culling of the animal (Gröhn et al., 1998). Morphology of retained bovine placentae may be characterized by the incomplete 'maturation', that is, the insufficient reduction in the number of maternal crypt epithelial cells during the prepartum period (for example, see Schulz and Merkt, 1956; Björkman and Sollen, 1961). This finding implies that homeostasis of placental tissue plays an important role in placental physiology and pathology, that is, growth, maturation, release or retention of fetal membranes. Up to now,

Email: boosa@vetanat.unizh.ch no quantitative studies dealing with proliferation and apoptosis, including entire pregnancy and spontaneous delivery with or without retention of fetal membranes have been performed, leaving a gap in our knowledge about the significance of homeostasis of placental tissue. Recent studies dealing with progesterone, oestrogen and glucocorticoid receptors in the bovine placenta at identical tissue probes (Boos et al., 2000) should, combined with results of the present study, give new insights into the regulation of this process. New histochemical techniques, such as detection of $\mathrm{Ki}-67$ protein and the terminal deoxynucleotidyl transferase-mediated dUTPbiotin nick end labelling (TUNEL) procedure, allow a more precise quantification of cell proliferation and death, consequently resulting in a better understanding of these processes. 
Uterine and placental growths are prerequisites for the adequate supply of nutrients and oxygen to the fetus. The mass of the bovine uterus increases from approximately $0.6 \mathrm{~kg}$ to about $10.0 \mathrm{~kg}$ during pregnancy (Prior and Laster, 1979; Ferrell, 1991; Rüsse and Grunert, 1993) and placental mass is approximately $5.0 \mathrm{~kg}$ at the end of pregnancy (Laven and Peters, 2001). Although the maternal caruncles grow throughout gestation, the growth of the cotyledons ceases, and their mass may even decrease beyond month 7 of gestation in cows (Prior and Laster, 1979; Reynolds et al., 1990; Ferrell, 1991). This finding is reflected by reduced growth rates of the cotyledons (Prior and Laster, 1979; Anthony et al., 1986) and a change in the ratio of maternal:fetal tissues within the placentome. The ratios are $1: 1$ during months $1-3,1.5-1.6: 1$ during months 4-7 and 1.8:1 during months 8 and 9 (Laven and Peters, 2001).

The increase in uterine mass can be achieved by cellular proliferation or hypertrophy. Histological, histochemical and biochemical studies of ruminant placentomes and interplacental tissues indicate that it is mainly cell proliferation that facilitates the increase in placental tissue mass (Björkman, 1969; Anthony et al., 1986; Reynolds et al., 1990; Wooding et al., 1993; Zheng et al., 1996). However, the increase in maternal interplacental tissue is largely achieved by hypertrophy (Reynolds et al., 1990; Zheng et al., 1996).

Degeneration of maternal crypt epithelial cells, and to a lesser extent of trophoblast epithelial cells, is detectable throughout pregnancy, reflecting normal tissue turnover and indicating a contribution of the maternal epithelium to embryotrophe (Björkman, 1954, 1969; King et al., 1979, 1981; Hoffmann and Schuler, 2002). Towards the end of pregnancy, placental 'maturation' is initiated. In cows, this process is characterized histologically by a number of changes that occur mainly in maternal crypt epithelium. The height and number of these cells decrease, the cells flatten and broaden and establish contact with an increased number of fetal trophoblastic cells as well as with a larger area of the underlying maternal connective tissue. Areas denuded of epithelial cells may also result within the maternal epithelial lining of the crypts. Placental maturation shortens the distance between the fetal and maternal blood supplies and is the main mechanism by which the placenta meets the growing demand of the fetus in the last months of pregnancy. Placental maturation is supposed to be a prerequisite for the sub-partal detachment and release of the fetal membrane (Björkman, 1954; Björkman and Sollen, 1960; Woicke et al., 1986; Williams et al., 1987; Schoon, 1989; Stallmach et al., 2001). Finally, giant trophoblast cells are reduced in number before normal term (Margolis et al., 1983; Woicke et al., 1986; Williams et al., 1987; Schoon, 1989; Gross et al., 1991).

Ki-67 immunohistochemistry and the TUNEL procedure (verified at the ultrastructural level) were used in the present study to quantify cellular proliferation and cell death and to assess their contribution to placental tissue growth, regeneration and maturation during normal pregnancy. The quantitative morphological examination focused on detection of alterations in tissue homeostasis that can result in retention of the fetal membranes and provide new insights into the pathogenesis of this important puerperal syndrome.

\section{Materials and Methods}

\section{Animals}

The uteri of 45 pregnant Holstein-Friesian cows were collected at slaughter. The cows were in month 1-9 of gestation with five cows in each month. Animals were eviscerated $30 \mathrm{~min}$ after they were killed; the pregnant uteri were opened; the crown-rump length of the fetuses was measured; and the fetal age was estimated as follows: up to $1.5 \mathrm{~cm}$, month $1 ; 2.0-3.3 \mathrm{~cm}$, month 2; $6.8-8.0 \mathrm{~cm}$, month $3 ; 15.5-23.0 \mathrm{~cm}$, month $4 ; 27.0$ $31.5 \mathrm{~cm}$, month $5 ; 36.0-44.0 \mathrm{~cm}$, month $6 ; 48.0$ $53.0 \mathrm{~cm}$, month 7; 60.0-66.0 cm, month 8 and 79.0 $81.5 \mathrm{~cm}$, month 9 of gestation (Schnorr and Kressin, 2001). The contents of the uteri in month 1 of gestation were examined histologically for embryonic tissue if the embryo was not found macroscopically. The cows were finally subdivided into three prepartum groups corresponding to trimesters one to three. For statistical purposes, slaughtered cows that were in month 9 of pregnancy were combined in a separate group for comparison with the following peripartal groups.

Five prepartum cows (group SEC) were housed in the Clinic for Bovine Obstetrics and Gynaecology, School of Veterinary Medicine, Hanover, for at least 3 days and received $1 \mathrm{mg}$ Cloprostenol $^{\circledR}$ per animal (Estrumate ${ }^{\circledR}$, Essex, Munich). Caesarean sections were performed at days $269,273,275,278$ or 282 after insemination and $27 \mathrm{~h}$ after prostaglandin application (1 $\mathrm{mg}$ Cloprostenol per animal; Estrumate $\left.{ }^{\circledR}\right)$. No clinical signs of parturition were observed. Caesarean sections were performed under local anaesthesia (Procaine (Isocaine, 2\% solution, Selectavet, Weyarn), $40 \mathrm{ml}$ paravertebral and $80 \mathrm{ml}$ at the site of the incision) and a single placentome was collected. Blood samples from the jugular vein were obtained immediately before the administration of a prostaglandin $\mathrm{F}_{2 \alpha}\left(\mathrm{PGF}_{2 \alpha}\right)$ analogue and immediately before the Caesarean section. Plasma was stored at $-20^{\circ} \mathrm{C}$ for subsequent measurement of progesterone and oestrogens (Hoffmann et al., 1973). Hormone analysis was carried out in the endocrine laboratory of the clinic using radioimmunoassay. All five cows retained their fetal membranes.

Additional material was obtained within $1 \mathrm{~h}$ after the expulsion of the fetus from five spontaneously calving cows (group REL) which had discharged their fetal membranes within $12 \mathrm{~h}$ after parturition and from five cows retaining their secundinae for $>12 \mathrm{~h}$ (group RET). These cows belonged to the University's dairy herd or 
were under medical treatment in the clinic and were routinely examined for the release of the fetal membranes at least 3, 6 and $12 \mathrm{~h}$ after birth and, thus, subdivided retrospectively into groups REL or RET.

Animal experiments were approved by the administration of the district Hanover, and performed according to the German Law for the Protection of Animals (TierschG) and the recommendations of the German Society of Laboratory Animal Science (GV-SOLAS).

\section{Tissue sampling and processing}

At slaughter, at least two randomly selected placentomes were excised in the region of the allantochorion from each cow. The caruncles, the adhering allantochorion and the surrounding segment of the uterine wall were excised from the uterine horn ipsilateral to the corpus luteum in the early stages of gestation. A single placentome was collected from the pregnant uterine horn of cows belonging to groups SEC, REL and RET. For excision of placentomes from live cows (REL and RET) an elongated effeminator according to Reisinger (1906), modified by Richter (1936) (Hauptner, Solingen) was used. The central portion of the placentomes was cut in four to six cross-sections of $5 \mathrm{~mm}$ in thickness. The slices were immersed in $4 \%(\mathrm{v} / \mathrm{v})$ neutral buffered formaldehyde solution according to Lillie (1954) (Böck, 1989) for $24 \mathrm{~h}$, rinsed in tap water, dehydrated in a graded series of ethanol and acetic acid- $n$-butyl ester (Riedel-de-Haën, Seelze) and embedded in Paraplast Plus ${ }^{\circledR}$ (Sheerwood Medical, St Louis, MO).

In addition, small tissue strips measuring $1 \mathrm{~mm}$ in thickness and $3 \mathrm{~mm}$ in width reaching from the allantoic sac orientated convex edge to the myometrium orientated concave side of the placentomes were immersed into formaldehyde-glutaraldehyde fixative according to Karnovsky (1965), post-fixed in $1 \%(\mathrm{w} / \mathrm{v}) \mathrm{OsO}_{4}$ and embedded in $\mathrm{EPON}^{\circledR}$ (Serva, Heidelberg).

\section{Light microscopy and transmission electron microscopy}

Paraplast sections were cut at $3 \mu \mathrm{m}$ in thickness $\left(1140 /\right.$ Auto-cut $\left.^{\circledR}\right)$ and stained with haematoxylin-eosin and Masson-Goldners trichrome stain (Böck, 1989). Semithin sections of selected placentomes were stained with methylene blue and fuchsin according to Morgenstern (1969), observed under a light microscope and ultrathin sections were prepared from selected regions of interest using an Ultracut ${ }^{\circledR}$ microtome (Reichert-Jung). The sections were stained with methanolic uranyl acetate and lead citrate (Reynolds, 1963; Stempak and Ward, 1964) and assessed for apoptotic cells and bodies using a Zeiss-EM $10^{\circledR}$ electron microscope (Zeiss, Oberkochen).

\section{Immunohistochemistry of proliferating cells}

For the demonstration of the Ki-67 antigen, tissue sections of $3 \mu \mathrm{m}$ in thickness were mounted on to
Histo-Bond Superior ${ }^{\circledR}$ adhesive slides (Marienfeld, Bad Mergentheim). Sections were dewaxed in xylene, rinsed in isopropyl alcohol, hydrated through descending grades of ethanol and rinsed in PBS (Merck, Darmstadt). Tissue-specific endogen peroxidases were inhibited by incubating slides in $80.0 \%(\mathrm{v} / \mathrm{v})$ ethanol supplemented with $0.5 \%(\mathrm{v} / \mathrm{v})$ hydrogen peroxide during hydration. Subsequently, antigen retrieval (Shi et al., 2001) was carried out by incubating the sections in $0.01 \mathrm{~mol}$ citrate buffer $\mathrm{I}^{-1}$ ( $\mathrm{pH}$ 6.0) (Merck, Darmstadt) in a microwave oven $(600 \mathrm{~W}, 1 \times 10 \mathrm{~min}$ and $6 \times 5 \mathrm{~min})$. Sections were encircled with a Dako Pen ${ }^{\circledR}$ (Dako, Hamburg) and blocking was performed by incubating sections in a humid chamber for $20 \mathrm{~min}$ with $20 \%(\mathrm{v} / \mathrm{v})$ normal horse serum in PBS at room temperature $\left(20-22^{\circ} \mathrm{C}\right)$. Sections were incubated with a monoclonal anti-Ki-67 antibody (MIB1, Dianova, Hamburg; diluted 1:100 in PBS) in a humid chamber at $4^{\circ} \mathrm{C}$ for $12 \mathrm{~h}$. After rinsing $(3 \times 5 \mathrm{~min})$ in PBS, receptor-antibody complexes were visualized using the Vectastain Elite ${ }^{\circledR} A B C$ kit (Vector, Burlingame, CA). The sections were incubated for $60 \mathrm{~min}$ at room temperature with secondary antibodies (horse anti-mouse IgG) diluted 1:200 in PBS, rinsed in PBS $(3 \times 5 \mathrm{~min})$ and the avidin-biotinylated peroxidase complex $(A B C)$ reagent was applied for $60 \mathrm{~min}$. The sections were treated with $0.07 \%(\mathrm{w} / \mathrm{v})$ diaminobenzidine tetrahydrochloride chromogen for 8 min, rinsed with distilled water $(3 \times 5 \mathrm{~min})$, counterstained with haemalaun according to Mayer (1920) (Böck, 1989), rinsed in tap water for $10 \mathrm{~min}$, dehydrated, cleared in xylene and a coverslip was added with Eukitt ${ }^{\circledR}$ (Kindler, Freiburg). Negative controls were produced using PBS instead of the primary antibodies. The specificity of the immunoreaction was confirmed by the absence of staining in controls. Sections of young cyclic corpora lutea served as positive controls.

\section{TUNEL staining}

Apoptotic cells were detected in situ using the TUNEL method of Gavrieli et al. (1992) with minor modifications (Negoescu et al., 1996). Deparaffinized sections were hydrated, rinsed in TBS buffer $(\mathrm{pH} \mathrm{7.6)}$ for $5 \mathrm{~min}$ and treated with proteinase $\mathrm{K}\left(10 \mu \mathrm{g} \mathrm{ml} \mathrm{m}^{-1}\right.$, Sigma) in TBS buffer for $15 \mathrm{~min}$ at room temperature. Sections were then rinsed several times in double distilled water (DDW) and tissue specific peroxidases were quenched in $2 \%(\mathrm{v} / \mathrm{v})$ hydrogen peroxide solution (Merck) for $5 \mathrm{~min}$ at room temperature, and then rinsed three times in DDW for $2 \mathrm{~min}$ and incubated in TdT buffer $(\mathrm{pH} \mathrm{7.2)}$ for $10 \mathrm{~min}$. Incubation of sections in TdT buffer containing terminal deoxynucleotidyl transferase (50 iu per $50 \mu \mathrm{l}$, Sigma) and biotin-16'-2'-dUTP (50 nmol per $50 \mu \mathrm{l}$, Boehringer, Mannheim) at $4^{\circ} \mathrm{C}$ overnight in a humid chamber was followed by stopping the reaction in termination buffer (300 mmol sodium chloride $\mathrm{I}^{-1}$ and $30 \mathrm{mmol}$ sodium citrate $\mathrm{I}^{-1}$ ) for $15 \mathrm{~min}$ at room temperature. Subsequently 
sections were rinsed three times in PBS and immersed in $2 \%$ BSA in TBS buffer for $10 \mathrm{~min}$ at room temperature. Two rinses in TBS for $10 \mathrm{~min}$ each were followed by covering the plates with streptavidine-biotin complex (VECTASTAIN ${ }^{\circledR}$-Elite ABC mouse IgG kit, Vector) in TBS buffer for $30 \mathrm{~min}$ at room temperature and two rinses in TBS for 5 min each. Staining with diaminobenzidine $\left(0.06 \%\right.$, w/v) in TBS at pH 7.6 and $0.002 \%(v / v) \mathrm{H}_{2} \mathrm{O}_{2}$ for $8 \mathrm{~min}$ was followed by rinsing in DDW, counterstaining with haemalaun according to Mayer (Böck, 1989), dehydrating and mounting in Eukitt ${ }^{\circledR}$ (Kindler). For negative controls, sections were incubated without terminal deoxynucleotidyl transferase. Sections of old regressing cyclic bovine corpora lutea served as positive controls.

\section{Quantification procedures of proliferating and apoptotic cells}

Proliferating cells were counted at a magnification of $\times 500$. Immunopositive and immunonegative cells of all types within the placental tissue were counted. Three microscopic fields each of $0.5 \mathrm{~mm}$ in diameter were randomly selected in allantoic sac orientated convex and myometrium orientated concave parts of the placentome. The results were expressed as the percentage of immunopositive cells counted per tissue region in relation to the total numbers of each type of cell. The numbers of cells counted per field were: (i) maternal crypt epithelial cells including giant cells: 50-200 cells during month 1 , $300-500$ cells during months $2-4,200-300$ cells during months 5-9 and 100-150 cells in spontaneously calving animals; (ii) fetal chorionic epithelial cells including giant cells: $30-150$ cells during month 1, 150-300 cells during months 2-9 in spontaneously calving animals; and (iii) connective tissue cells of the maternal crypt stroma: 100-200.

The number of TUNEL-positive cells that had clear morphological signs of apoptosis (Fig. 2i) and of apoptotic bodies was counted in six randomly selected microscopic fields per tissue region, that is, convex and concave halves of the placentome. The total number of apoptotic cells and bodies per type of cell was used for further statistical evaluation. The localization of an apoptotic body and cell was used to classify it as maternal or fetal, respectively, because the uniform morphology of these bodies did not always indicate its exact cellular origin. However, it should be emphasized that TUNELpositive, morphologically intact cells were not included in the results presented here.

\section{Statistical analysis}

No differences between the two evaluated tissue regions, concave and convex halves, were detectable, so the mean value of all microscopic fields assessed in a placentome was used for further statistical analysis and data were evaluated by a two-way ANOVA for repeated measurements (pregnancy stage and type of cell) using StatView ${ }^{\circledR}$ software. Significant differences between stages of pregnancy (first to third trimester; month 9 of pregnancy and groups SEC, REL and RET) and types of cell were evaluated using Bonferroni-Dunn test (SAS Inst., 1999). Analysis was performed for mean percentages of Ki-67-positive cells and mean numbers of TUNELpositive, morphologically apoptotic cells and apoptotic bodies that were counted in six (Ki-67) or 12 (apoptosis) fields per tissue probe. Differences between progesterone and oestrogen concentrations in plasma samples of cows undergoing premature Caesarean sections were compared using the Student's $t$ test for paired data.

\section{Results}

\section{Cellular proliferation (Ki-67 immunohistochemistry)}

In tissue sections, immunopositive cells were identified by brown staining of their nuclei, whereas immunonegative cells have blue counterstained nuclei (Fig. 1). All types of placental cell demonstrated $\mathrm{Ki}-67$ protein at different staining intensities depending on the stage of the cell cycle (Fig. 1). More than $40 \%$ of the maternal crypt epithelial cells, including giant cells, exhibited $\mathrm{Ki}-67$ immunoreactivity during the first two trimesters of gestation. This finding was reflected by the predominant chain-like arrangement of immunopositive cells, interrupted only by single, counterstained cells (Fig. 1b-e). The length of the mostly continuous chains of positive cells decreased with ongoing pregnancy. Immunopositive cells exhibited predominantly round or oval nuclei, but towards the end of gestation, extremely flat cells occurred in increasing numbers.

The percentage of positive fetal chorionic epithelial cells including giant cells showed distinct individual variations (Fig. 1). The mean individual number of immunopositive cells ranged from 13 (month 3 ) to $88 \%$ (month 3) during gestation. The number of positively stained cells decreased significantly (see Table 1 ) between the first and the third trimester. A significant decrease was also found between the month 9 group and the peripartal groups of animals (SEC, REL and RET; Fig. 1a-g versus $h$ and i). The fetal chorionic epithelium exhibited fewer Ki-67-positive cells than the adjacent maternal epithelium (second and third trimester) but more than the maternal (first to third trimester, SEC) and the fetal stroma (Fig. 1). The difference between the results of these types of cell was not significant in the animals of the SEC, REL and RET groups. In giant cells, up to two positively stained nuclei were found.

The percentage of Ki-67-positive maternal crypt epithelial cells including giant cells, also showed distinct variations between individual cows (Fig. $1 \mathrm{~d}$ and $\mathrm{f}$ versus e and $\mathrm{g}$ ). This variation was reflected by relatively large standard errors of the mean (Table 1). Mean numbers of 

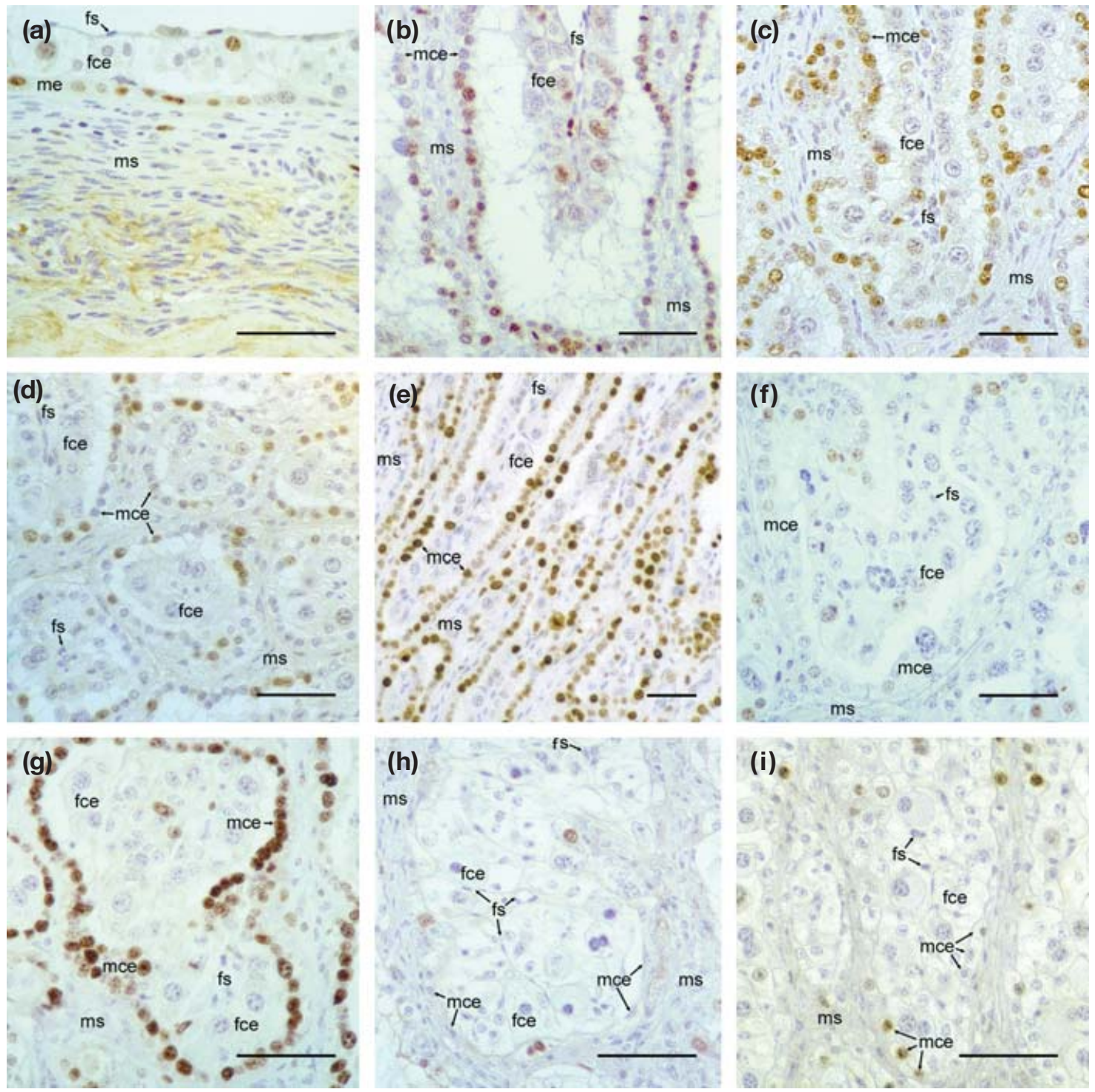

Fig. 1. Immunohistochemical demonstration of Ki-67 protein (brown staining of nucliei) in bovine placentomes at month (a) 1, (b) 2, (c) 3, (d,e) 4 and (f,g) 9 of pregnancy, (h) premature Caesarean section and (i) retention of the fetal membranes; maternal caruncular or crypt epithelia (me/mce) exhibit the strongest Ki-67 staining intensities in all specimens in comparison with fetal chorionic epithelium ( $f(c)$ and maternal as well as fetal stromal cells $(\mathrm{ms} / \mathrm{fs}$ ). $(\mathrm{a}-\mathrm{c})$ Initial placental growth is reflected by uniformly high immunoreactivities up to month 3 of pregnancy. $(\mathrm{d}-\mathrm{f})$ Months 4-9 of pregnancy are characterized by highly variable immunostaining intensities. (h,i) Peripartal probes exhibit a weak Ki-67 immunoreactivity. Scale bars represent $50 \mu \mathrm{m}$.

immunopositive cells ranged from 0.0 (one animal only, first month) to $89.5 \%$ (third month) during pregnancy. There was a decrease in $\mathrm{Ki}-67$-positive cells between the second and third trimester, but this difference was not significant. A significant reduction in Ki-67-positive cells occurred between placentomes collected at the abattoir during month 9 of gestation and those obtained from animals at Caesarean section and immediately after the expulsion of the fetus (groups SEC, REL and RET; Fig. 1a-g versus $h$ and i). The maternal crypt epithelium contained a higher percentage of immunopositive cells $(P<0.05)$ compared with the fetal chorionic epithelium (second and third trimester) as well as the maternal and fetal stroma (first to third trimesters; Fig. 1, Table 1).

Only a few stromal cells were positive for $\mathrm{Ki}-67$ ranging from 0 (26 samples in total) to $40 \%$ in individual animals (Fig. 1). In general, Ki-67 staining in maternal and fetal stroma was low. In maternal and fetal $(4.1 \pm$ $0.7 \%$ ) stromal cells no significant differences in percentages of Ki-67-positive cells were detectable. In some sections capillary endothelial cells were easily detectable, whereas in others they could not clearly be distinguished from stromal fibrocytes. These endothelial cells (data not shown) were generally immunopositive for $\mathrm{Ki}-67$ with 
Table 1. Percentage of Ki-67-positive cells in six microscopic fields (mean \pm SEM) in different types of cell and reproductive stage in cows

\begin{tabular}{|c|c|c|c|c|c|c|c|}
\hline \multirow[b]{2}{*}{ Type of cell } & \multicolumn{7}{|c|}{ Stage of pregnancy } \\
\hline & 1 st trimester & 2nd trimester & 3rd trimester & Month 9 & SEC & REL & RET \\
\hline Fetal chorionic epithelium & $40.8 \pm 4.7^{\mathrm{a}, \mathrm{A}}$ & $30.1 \pm 2.8^{\mathrm{C}}$ & $26.2 \pm 1.5^{\mathrm{b}, \mathrm{F}}$ & $25.3 \pm 2.2^{\mathrm{c}, \mathrm{I}}$ & $13.0 \pm 2.5^{\mathrm{d}}$ & $13.1 \pm 3.0^{d}$ & $12.9 \pm 0.6^{\mathrm{d}}$ \\
\hline Maternal crypt epithelium & $42.9 \pm 5.2^{\mathrm{A}}$ & $46.5 \pm 4.7^{\mathrm{D}}$ & $34.3 \pm 2.8^{\mathrm{G}}$ & $32.0 \pm 4.5^{\mathrm{e}, \mathrm{I}}$ & $14.1 \pm 1.7^{f}$ & $10.2 \pm 2.2^{f}$ & $11.7 \pm 1.9^{f}$ \\
\hline Maternal stromal cells & $10.8 \pm 3.6^{\mathrm{B}}$ & $3.5 \pm 1.9^{\mathrm{E}}$ & $6.9 \pm 2.1^{\mathrm{H}}$ & $6.5 \pm 4.4^{\jmath}$ & $5.9 \pm 2.7$ & $8.8 \pm 2.7$ & $6.8 \pm 2.2$ \\
\hline
\end{tabular}

Values within a row are significantly different $(P<0.05)$ as follows: a and b, c and $\mathrm{d}$, e and $\mathrm{f}$.

Values within a column are significantly different $(P<0.05)$ as follows: $\mathrm{A}$ and $\mathrm{B}, \mathrm{C}$ and $\mathrm{D}$ and $\mathrm{E}, \mathrm{F}$ and $\mathrm{G}$ and $\mathrm{H}, \mathrm{I}$ and $\mathrm{J}$.

Number of animals in each group: first, second and third trimester ( $n=15$ cows per group); month 9 of pregnancy, SEC: prepartum cows, REL: spontaneously calving cows which had discharged their fetal membranes and RET: spontanesouly calving cows that retained their secundinae ( $n=5$ cows per group).

Data of probes collected from animals during the 9th month of pregnancy are also included in the third trimester group.

no obvious patterns visible during gestation and in the peripartal period.

\section{Apoptosis (TUNEL method and electron microscopy)}

During pregnancy, apoptosis as assessed by TUNEL staining, morphology of the cells and presence of apoptotic bodies, was extremely low (Fig. 2). This reduced apoptosis continued up to $24 \mathrm{~h}$ after the administration of a $\mathrm{PGF}_{2 \alpha}$ analogue at the time of premature Caesarean section (Fig. 2a-g). Apoptotic cells were located most frequently between the maternal and fetal epithelial cells as well as lying between these two epithelia (Figs 2c-f,i and $3 a, b)$. In general, apoptotic cells were smaller than neighbouring epithelial cells and were not in contact with the underlying basement membrane (Figs 2 and 3). TUNEL-positive nuclei or their fragments were stained brown (Fig. 2) and in some instances the blue stain of the condensed chromatin was clearly visible within the cells and bodies (Fig. 2,i). The apoptotic bodies were sometimes visibly engulfed by adjacent fetal or maternal epithelial cells. Apoptotic placental giant cells had two pycnotic nuclei lying close together in a round cell of reduced size. Apoptotic stromal cells and bodies without cytoplasmic remnants were scattered between connective tissue fibres. Small secondary or tertiary fetal chorionic villi showed complete degeneration immediately after birth and apoptotic bodies contributed to the composition of the detritus within the lumen of maternal crypts (Fig. 2g).

Electron microscopy, performed to verify the TUNEL procedure - revealed characteristic apoptotic bodies either within intact maternal or fetal epithelial cells (Fig. 3c,d) or lying between maternal and fetal epithelial linings (Fig. 3a,b). Nuclear remnants were composed of electron dense chromatin residues and fine granules surrounded by an intact nucleolemma (Fig. 3a,b,d). Cytoplasmic compartments consisted of cisternae of smooth and rough endoplasmic reticulum, mitochondria with intact or partly destroyed cristae, multi-vesiculated and multi-lamellated bodies and finally electron dense vesicles (Fig. 3a-c). Individual apoptotic bodies were usually surrounded by an intact plasmalemma devoid of specialized surface structures, such as microvilli or cell junctions (Fig. 3a,b,d,e).

Apoptotic cells and bodies were commonly found within the fetal chorionic epithelium as well as in the giant cells. Only three samples (obtained from cows in early pregnancy) of 45 samples collected from cows throughout pregnancy did not show any signs of apoptosis within the fetal epithelium. There was a significant increase in apoptotic cells and bodies between the first and second trimesters and the third trimester as well as between the groups month 9, SEC and REL and the RET group (Table 2; Fig. 2a-h). Fetal chorionic epithelium exhibited a significantly higher number of apoptotic cells and bodies, compared with the maternal crypt epithelium or stroma (all stages excluding month 9, Table 2).

In the maternal crypt epithelial cells including giant cells, apoptotic cells or bodies could not be detected at all in 12 fields assessed in 26 of 45 placentomes collected at slaughter. One, eight and ten placentomes of 15 samples contained one to six apoptotic bodies each in 12 fields during the first, second or third trimester, respectively (Fig. 2a-f). The mean number of apoptotic cells and bodies increased significantly from the first to the third trimester (Table 2). Peripartal groups did not differ in this respect. Mean numbers of apoptotic cells and bodies in the maternal epithelium were significantly lower than those detected in fetal epithelium (all stages excluding month 9, Table 2). In the maternal stroma, only very few apoptotic cells and bodies were present (see Table 2; Fig. 2). Twenty-three placentomes collected at the abattoir were completely devoid of apoptotic maternal stromal cells. The number of sections exhibiting apoptosis increased with the stage of gestation. Apoptosis was detected in three, nine and ten of 15 sections each during the first, second and third trimester, respectively. In the peripartal period apoptosis was shown in three, three, four, and two of five sections in the month 9, SEC, REL and RET groups, respectively. There was a significant difference in the number of apoptotic cells and bodies between the first and the third trimester. Peripartal groups 

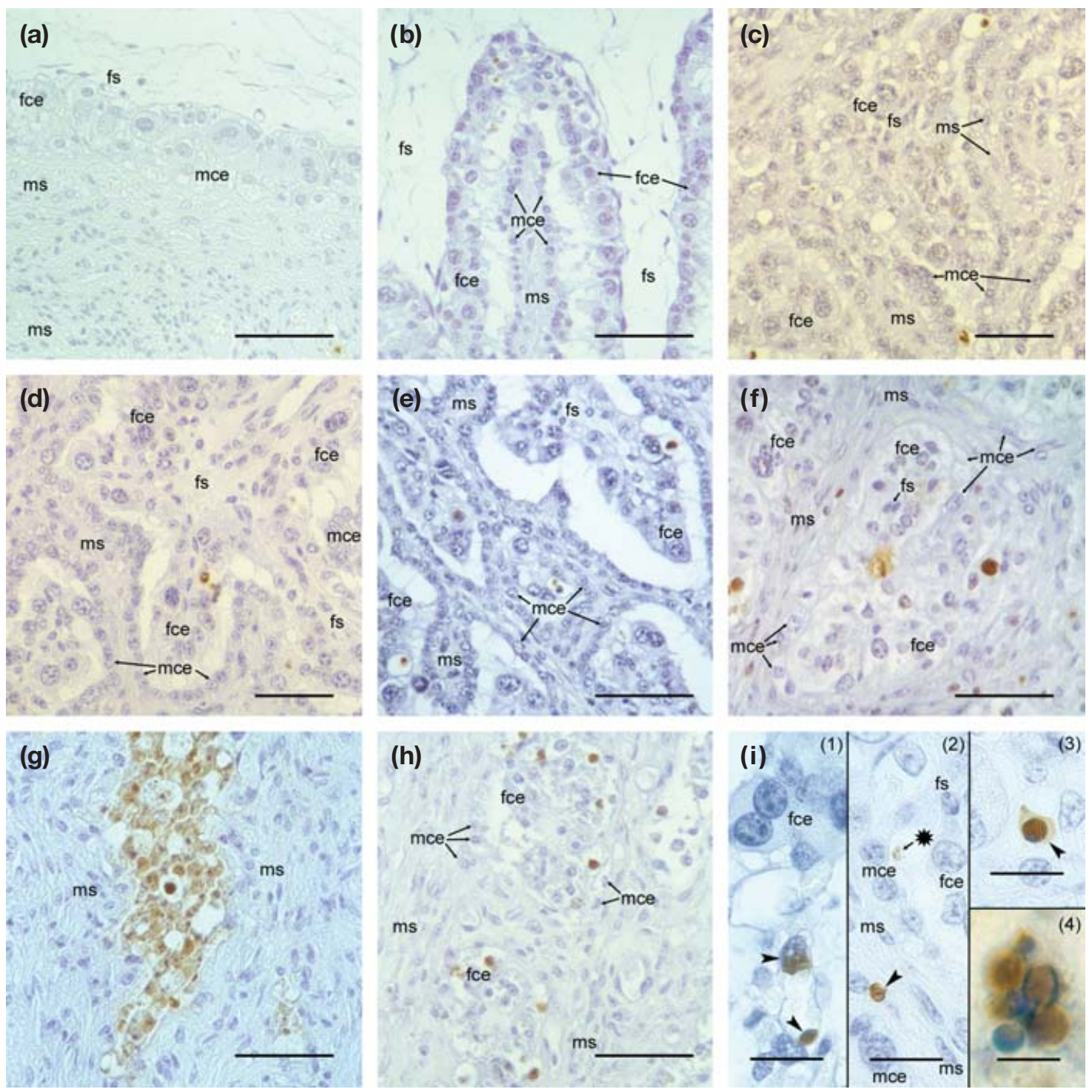

Fig. 2. Terminal deoxynucleotidyl transferase-mediated dUTP-biotin nick end labelling (TUNEL) reaction in bovine placentomes at month (a) 1, (b) 2, (c) 6, (d) 8 and (e) 9 of pregnancy, (f,g) $<1 \mathrm{~h}$ after spontaneous parturition, (h) retention of the fetal membranes and $(\mathrm{i}, 1)<1 \mathrm{~h}$ after spontaneous parturition, $(\mathrm{i}, 2,3)$ month 8 of pregnancy and $(i, 4)$ premature Caesarean section. Apoptosis (brown stained apoptotic bodies) occurs at highest rates within the fetal chorionic epithelium (fce), at lower rates within the maternal crypt epithelium (mce) and at lowest rates in the maternal stroma (ms) and fetal stroma $(\mathrm{fs}) .(\mathrm{a}, \mathrm{b})$ Apoptosis is a rare event during the first trimester. (c-e) Increased numbers of apoptotic bodies are visible during the second and third trimester. (f) After spontaneous parturition more apoptotic bodies occur and (g) some degenerated fetal chorionic villi containing apoptotic bodies can be seen. (h) The highest number of apoptotic bodies is present in retained placentomes. (i) Apoptotic bodies are shown at higher magnifications. Capillary endothelial cells $(\mathrm{i}, 1)$, arrowheads, maternal stromal cells (ms), arrowhead, or cells within the space between maternal crypt epithelium (mce) and fetal chorionic epithelium (fce) (i,2), asterisk, and (i,3) are involved. A cell during blebbing between maternal and fetal epithelium is shown $(\mathrm{i}, 4)$. Scale bars represent $(\mathrm{a}-\mathrm{h})$ $50 \mu \mathrm{m}$, (i inserts 1-3) $15 \mu \mathrm{m}$ and (i insert 4) $5 \mu \mathrm{m}$.

exhibited no change in the number of apoptotic cells and bodies.

Fetal stroma exhibited only very few apoptotic cells and bodies $(0.83 \pm 0.15 \%)$. No definite pattern during pregnancy and peri-partum groups could be established (data not shown, also see Fig. 2).

\section{Steroid hormone concentrations in peripartal cows}

The progesterone concentrations declined significantly $\left(42.6 \pm 5.4\right.$ versus $\left.10.2 \pm 2.0 \mathrm{nmol} \mathrm{I}^{-1} ; P<0.05\right)$, whereas the concentrations of total oestrogens increased significantly $\left(438 \pm 57\right.$ versus $\left.529 \pm 49 \mathrm{pg} \mathrm{I}^{-1} ; P<0.05\right)$ 

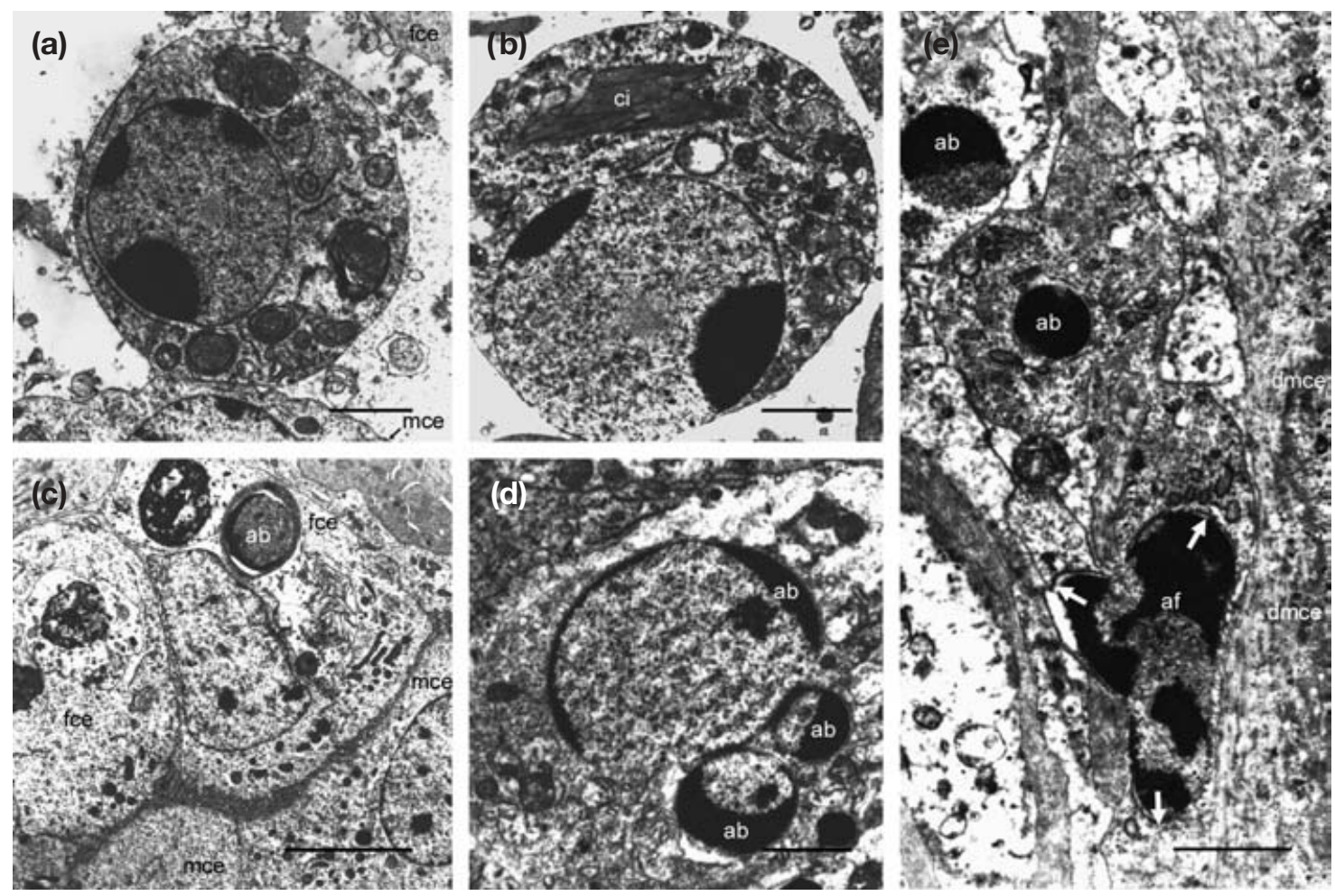

Fig. 3. Transmission electron microscopy of $(a, b)$ bovine apoptotic bodies lying between the maternal crypt epithelium (mce) and the fetal chorionic epithelium (fce) and exhibiting different cytoplasmic inclusions, such as crystal inclusions (ci). (c,d) Apoptotic bodies of different size (ab) are also present within the fetal chorionic epithelium. (e) Apoptosis is a rare event within the stroma. Apoptotic bodies (ab) and a fibrocyte during blebbing (af) are demonstrated within the maternal stroma adjacent to a degenerated maternal crypt epithelium (dmce). Arrows indicate the direction of nuclear blebbing. Scale bars represent $(a, b, d, e) 2 \mu \mathrm{m}$ and (c) $10 \mu \mathrm{m}$.

Table 2. Mean number of morphologically apoptotic, TUNEL-positive cells detected in 12 microscopic fields (mean \pm SEM) in different types of cell and reproductive stage in cows

\begin{tabular}{lccccccc}
\hline & \multicolumn{5}{c}{ Stage of pregnancy } \\
\cline { 2 - 7 } Type of cell & 1st trimester & 2nd trimester & 3rd trimester & Month 9 & SEC & REL & RET \\
\hline Fetal chorionic epithelium & $3.0 \pm 0.8^{\mathrm{a}, \mathrm{A}}$ & $4.2 \pm 0.8^{\mathrm{a}, \mathrm{C}}$ & $10.5 \pm 1.8^{\mathrm{b}, \mathrm{E}}$ & $11.4 \pm 5.3^{\mathrm{c}}$ & $13.2 \pm 4.0^{\mathrm{c}, \mathrm{G}}$ & $26.8 \pm 7.2^{\mathrm{c}, \mathrm{l}}$ & $65.2 \pm 9.6^{\mathrm{d}, \mathrm{K}}$ \\
Maternal crypt epithelium & $0.1 \pm 0.1^{\mathrm{e}, \mathrm{B}}$ & $1.1 \pm 0.4^{\mathrm{D}}$ & $1.9 \pm 0.5^{\mathrm{f}, \mathrm{F}}$ & $3.2 \pm 1.0$ & $1.6 \pm 0.8^{\mathrm{H}}$ & $7.2^{\mathrm{N}} \pm 2.6^{\mathrm{J}}$ & $9.4 \pm 3.1^{\mathrm{L}}$ \\
Maternal stromal cells & $0.3 \pm 0.2^{\mathrm{g}, \mathrm{B}}$ & $1.0 \pm 0.3^{\mathrm{D}}$ & $1.5 \pm 0.4^{\mathrm{h}, \mathrm{F}}$ & $1.8 \pm 1.0$ & $1.6 \pm 0.8^{\mathrm{H}}$ & $3.0 \pm 1.3^{\mathrm{J}}$ & $2.0 \pm 1.3^{\mathrm{L}}$ \\
\hline
\end{tabular}

Values within a line differ significantly $(P<0.05)$ as follows: $a$ and $b, c$ and $d$, e and $\mathrm{f}, \mathrm{g}$ and $\mathrm{h}$.

Values within a column are significantly different $(P<0.05)$ as follows: $\mathrm{A}$ and $\mathrm{B}, \mathrm{C}$ and $\mathrm{D}, \mathrm{E}$ and $\mathrm{F}, \mathrm{G}$ and $\mathrm{H}, \mathrm{I}$ and $\mathrm{J}$, and $\mathrm{K}$ and $\mathrm{L}$.

Number of animals in each group: first, second and third trimester $(n=15$ cows per group); month 9 of pregnancy, SEC: prepartum cows, REL: spontaneously calving cows which had discharged their fetal membranes and RET: spontanesouly calving cows that retained their secundinae ( $n=5$ cows per group).

Data of probes collected from animals during the 9th month of pregnancy are also included in the 3rd trimester group.

TUNEL: Terminal deoxynucleotidyl transferase-mediated dUTP-biotin nick end labelling.

in maternal blood between $\mathrm{PGF}_{2 \alpha}$ application and Caesarean section.

\section{Discussion}

The results of the present histochemical study provide evidence that both proliferation, as detected by $\mathrm{Ki}-67$ immunohistochemistry, and apoptosis, as visualized by the TUNEL method and verified by electron microscopy play an important role in placental function. Both processes were inversely proportional during gestation and near parturition. Cellular proliferation declines whereas cell death increases. The various types of placental cell had characteristic patterns, reflecting the 
specific functions of the different placental elements. No significant regional differences in $\mathrm{Ki}-67$ immunoreactivities and numbers of apoptotic cells and bodies could be detected within the various regions assessed in the present study. This aspect of regional placental physiology and morphology is, depending on the variables assessed, controversially discussed. Studies of glucocorticoid receptors, metalloproteinases and smooth muscle actin confirm the presence of such differences (Boos et al., 2000; Walter and Boos, 2001).

Patterns of Ki-67 immunoreactivity in fetal chorionic and maternal crypt epithelia indicate that proliferation plays an important role throughout pregnancy and is with ongoing gestation - more prominent in maternal than fetal epithelium. These growth patterns are reflected by the microscopic and macroscopic observations made by several authors. The maternal compartment has higher growth capacities compared with the fetal compartment and the growth rates develop in different ways during ongoing gestation (Björkman, 1954, 1969; Prior and Laster, 1979; Anthony et al., 1986; Reynolds et al., 1990; Ferrell, 1991; Schuler et al., 2000; Laven and Peters, 2001). However, an increase in connective tissue fibres (Kaidi et al., 1995; Boos and Stelljes, 2000) and vascularization (Reynolds and Redmer, 1995, Leiser et al., 1997, Pfarrer et al., 2000) also contributes to the overall increase in placental mass.

The proliferative capacities of stromal cells are comparatively low throughout pregnancy and sub-partu. This finding indicates that the increase in connective tissue is mainly based on fibre production as described by Boos and Stelljes (2000). The results of the present study also support the contention that maternal stromal cells may be involved in tissue breakdown in the peripartal period (Schulz and Grunert, 1959; Schoon, 1989; Sobiraj, 1992) as Ki-67 immunoreactivities do not decrease sub-partu when compared with maternal crypt epithelial cells.

The demonstrated high percentage of Ki-67-positive maternal crypt epithelial cells strongly indicates that these cells undergo massive proliferation and may contribute to the histiotrophic nutrition of the fetus (Björkman, 1954, 1969; Hoffmann and Schuler, 2002) or materno-fetal signal transduction. This indication is underlined by the observation that apoptotic bodies can frequently be found between the maternal and fetal epithelial linings and at a higher rate within the fetal chorionic epithelium than within the maternal crypt epithelium. Furthermore, denuded maternal septae were found opposite intact fetal epithelia containing apoptotic bodies, as occasionally seen in the present study. Several authors support this view by the detection of mainly secretory organelles within maternal epithelial cells (Schoon, 1989) and morphological (Björkman, 1954, 1969; Schoon, 1989, Pfarrer et al., 1998) as well as histochemical signs (Schoon, 1989) of phagocytosis within the fetal epithelium. As flattened maternal crypt epithelial cells, which are regularly present towards the end of pregnancy, are often $\mathrm{Ki}-67$-positive, the change in cell height could be the consequence of altered needs in metabolism rather than a sign of degeneration as assumed earlier (Margolis et al., 1983; Williams et al., 1987; Schoon, 1989; Al-Sadi et al., 1994; Stallmach et al., 2001).

The number of apoptotic bodies and cells within the fetal chorionic and maternal crypt epithelia significantly increases in somewhat different patterns during pregnancy and also sub-partu (month 9, SEC and REL versus RET). This finding indicates that apoptosis, although remaining detectable at a very low level, clearly reflects the beginning of tissue regeneration and continuing histiotrophic nutrition of the fetus, that is phagocytosis of maternal apoptotic epithelial cells - after an initial period of very rapid placental growth.

The very small numbers of apoptotic bodies in comparison with the high percentages of Ki-67-positive cells are a result of the different windows of detectability using histochemical techniques rather than related to the real and directly comparable numbers of the respective events. The duration of the mammalian cell cycle is very variable (Shackney and Shankey, 1999) and the Ki-67 protein is expressed over nearly $75 \%$ of this period (Guinebretière and Sabourin, 1997). However, apoptotic bodies are formed within a very short period of time, that is, within minutes to a few hours as a terminal event of apoptosis (for example, see Collins et al., 1997; Verhaegen, 1998; Cellerino et al., 2000; Chang et al., 2000; Rudolf et al., 2000; Maruyama et al., 2001). Subsequently, adjacent cells phagocytose these apoptotic bodies within a few minutes (Verhaegen, 1998) without leaving a visual trace, reducing the opportunity to detect apoptotic bodies and cells in a given tissue (Verhaegen, 1998). Consequently, the small number of visible apoptotic bodies should make the difference between the large number of cells in proliferation (Ki-67positive) and those needed for tissue growth.

Although the short period ( $27 \mathrm{~h}$ ) between the induction of parturition and the Caesarean section provides sufficient time to induce a significant shift in ovarian and placental steroid secretion as also confirmed by Takagi et al. (2002) and Zerbe et al. (2002), and a significant decrease in epithelial Ki-67 labelling, the number of apoptotic epithelial cells remains unchanged. This finding implies that placental maturation, that is reduction of maternal epithelial cells by apoptosis, as a prerequisite for the release of fetal membranes, is a more time-consuming process than induction of labour and expulsion of the fetus. Lack of time consequently must lead to placental retention. The decrease in epithelial proliferation that was detected in the present study by a significant difference between probes of the month 9 (abattoir) and the SEC group must be supported by an increase in crypt epithelial apoptosis to enable the proper release of the fetal membranes. Earlier studies also performed under similar experimental conditions support 
this hypothesis as retained placentae of animals during premature section and also during spontaneous delivery of the calf demonstrate non-complete morphological maturation leading to the clinical phenomenon of placental retention (Woicke et al., 1986, Schoon, 1989). The hormones that should play an important role in this process are oestrogens or glucocorticoids because respective receptors are expressed on maternal crypt epithelium but not fetal chorionic epithelium (Boos et al., 2000; Schuler et al., 2002). This hypothesis is supported by clinical observations that retention of fetal membranes is presumably correlated with lower preterm concentrations of oestrogens (Chew et al., 1979; Lotthammer, 1983; Grunert et al., 1989; Fürstenberg et al., 1990; Kankofer et al., 1996; Zhang et al., 1999; Wischral et al., 2001).

The increase in the number of apoptotic bodies in maternal and fetal epithelial cells in cows immediately after the expulsion of the fetus (RET and REL), compared with pregnant cattle (month 9 and SEC), reflects placental maturation (Björkman, 1954; Schulz and Merkt, 1956; Björkman and Sollen, 1960; Margolis et al., 1983; Willms, 1986; Woicke et al., 1986; Williams et al., 1987; Schoon, 1989; Sobiraj, 1992). Significantly more apoptotic bodies are detectable in fetal chorionic epithelial cells of animals retaining the fetal membranes as compared with cows releasing the fetal membranes properly. The same trend is visible in maternal crypt epithelium. This finding indicates, together with the overall larger number of epithelial cells, that the process of epithelial cell reduction is still in progress immediately after the expulsion of the fetus in cows with fetal membrane retention (Björkman and Sollen, 1961). The results of the present study also provide evidence that the absence of massive apoptosis in the immediate prepartal period (groups month 9 and SEC) is not the cause but rather the consequence of a changed endocrine pattern near parturition leading to the retention of fetal membranes.

The results of the present histochemical study demonstrate that proliferation and apoptosis exhibit patterns that are specific for the stage of gestation as well as for the individual types of cell during gestation and at term. Proliferation plays an important role in placental growth and together with apoptosis in cellular regeneration and histiotrophic nutrition of the fetus. Apoptosis is essential for placental maturation and the proper release of the fetal membranes. After the expulsion of the fetus, apoptosis possibly reflects reduced uterine and placental blood supply. This was verified by colour Doppler ultrasonography in a study by Leidl (2000). Time averaged velocity $\left(V_{\text {mean }}\right)$ and blood flow volume decreased within $3 \mathrm{~h}$ after the expulsion of the fetus to 70 and $75 \%$ of prepartal values, respectively. Pulsatility index increased to $125 \%$ of prepartal values during this period (Leidl, 2000). Further experimental investigations should include the time-dependent effects of different doses of oestrogens and glucocorticoids on the morphology and function of the various types of cell contributing to the fetal and maternal parts of the placentome.

The authors wish to thank E. Berger, N. Eyring, M. Gähle, A. Hug and G. Wirth for their skillful technical assistance and J. Kohtes and A. Stelljes for collecting tissue samples. The kind help of M. Hässig with statistics is gratefully acknowledged.

\section{References}

Al-Sadi HI, Majeed AF and Ridha AM (1994) Histopathology of retained bovine fetal membranes Theriogenology 42 273-278

Anthony RV, Bellows RA, Short RE, Staigmiller RB, Kaltenbach CC and Dunn TG (1986) Fetal growth of beef calves. II. Effect of sire on prenatal development of the calf and related placental characteristics Journal of Animal Science 62 1375-1387

Björkman NH (1954) Morphological and histochemical studies on the bovine placenta Acta Anatomica 22 Supplement 2 1-91

Björkman NH (1969) Light and electron microscopic studies on cellular alterations in the normal bovine placentome Anatomical Record $\mathbf{1 6 3}$ 17-30

Björkman NH and Sollen P (1960) Morphology of bovine placenta at normal delivery Acta Veterinaria Scandinavica 1 157-177

Björkman NH and Sollen P (1961) A morphological study on retentio secundinarum in cattle Acta Veterinaria Scandinavica 2 347-362

Böck P (1989) Romeis Mikroskopische Technik, 17th Edn. Urban and Schwarzenberg, Munich

Boos A and Stelljes A (2000) Immunohistochemical detection of collagen types I, III and IV in the bovine uterus during pregnancy Reproduction in Domestic Animals 35 174-175

Boos A, Kohtes J, Stelljes A, Zerbe H and Thole HH (2000) Immunohistochemical assessment of progesterone, oestrogen and glucocorticoid receptors in bovine placentomes during pregnancy, induced parturition, and after birth with or without retention of fetal membranes Journal of Reproduction and Fertility 120 351-360

Cellerino A, Galli-Resta L and Colombaioni L (2000) The dynamics of neuronal death: a time-lapse study in the retina Journal of Neuroscience 20 RC92 1-5

Chang SH, Phleps PC, Berezesky IK, Ebersberger ML, Jr and Trump BF (2000) Studies on the mechanisms and kinetics of apoptosis induced by microinjection of cytochrome $\mathrm{c}$ in rat kidney tubule epithelial cells (NRK-52E) American Journal of Pathology 156 637-649

Chew BP, Erb RE, Zamet CN, Colenbrander VF, Malven PV and D'Amico MF (1979) Variables associated with peripartum traits in dairy cows. V. Hormonal profiles associated with retained fetal membranes Theriogenology 12 245-253

Collins JA, SchandI CA, Young KK, Vesely J and Willingham MC (1997) Major DNA fragmentation is a late event in apoptosis Journal of Histochemistry and Cytochemistry 45 923-934

Ferrell CL (1991) Maternal and fetal influences on uterine and conceptus development in the cow: I. Growth of tissues of the gravid uterus Journal of Animal Science 69 1945-1953

Fürstenberg A, Busch W, Fürstenberg L and Münchow H (1990) Untersuchungen zur Ätiologie der Retentio secundinarum beim Rind Monatshefte für Veterinärmedizin 45 493-496

Gavrieli Y, Sherman Y and Ben-Sasson SA (1992) Identification of programmed cell death in situ via specific labelling of nuclear DNA fragmentation Journal of Cell Biology 119 493-501

Gröhn YT, Eicker SW, Nurocq V and Hertl JA (1998) Effect of diseases on the culling of Holstein dairy cows in New York State Journal of Dairy Science 81 966-978

Gross TS, Williams WF and Russek-Cohen E (1991) Cellular changes in the peripartum bovine fetal placenta related to placental separation Placenta 12 27-35

Grunert E, Ahlers D and Heuwieser W (1989) The role of endogenous estrogens in the maturation process of the bovine placenta Theriogenology 31 1081-1091 
Guinebretière JM and Sabourin JC (1997) Ki-67, marqueur de prolifération Annales de la Pathologie 17 25-30

Hoffmann B and Schuler G (2002) The bovine placenta; a source and target of steroid hormones: observations during the second half of gestation Domestic Animal Endocrinology 23 309-320

Hoffmann B, Schams D, Gimenez T, Ender ML, Herrmann C and Karg H (1973) Changes of progesterone, total oestrogens, corticosteroids, prolactin and LH in bovine peripheral plasma around parturition with special reference to the effect of exogenous corticoids and a prolactin inhibitor, respectively Acta Endocrinologica (Copenhagen) 73 385395

Kaidi R, Brown PJ, David JS, Etherington DJ and Robins SP (1995) Uterine collagen during pregnancy in cattle Veterinary Research 26 87-91

Kankofer M, Zdunczyk S and Hoedemaker M (1996) Contents of triglycerides and cholesterol in bovine placental tissue and in serum as well as concentration of oestrogens in cows with and without retained placental fetal membranes Reproduction in Domestic Animals 31 681683

Karnovsky MJ (1965) A formaldehyde-glutaraldehyde fixative of high osmolarity for use in electron microscopy Journal of Cell Biology 27 $137 \mathrm{a}$

King GJ, Atkinson BA and Robertson HA (1979) Development of the bovine placentome during the second month of gestation Journal of Reproduction and Fertility 55 173-180

King GJ, Atkinson BA and Robertson HA (1981) Development of the intercaruncular areas during early gestation and establishment of the bovine placenta Journal of Reproduction and Fertility 61 469-474

Laven RA and Peters RA (2001) Gross morphometry of the bovine placentome during gestation Reproduction in Domestic Animals 36 289-296

Leidl S (2000) Farbdopplersonographische Untersuchungen der uterinen Durchblutung im peripartalen und puerperalen Zeitraum des Rindes PhD Thesis, Ludwig-Maximilians-University Munich

Leiser R, Krebs C, Klisch K, Ebert B, Dantzer V, Schuler G and Hoffmann B (1997) Fetal villosity and microvasculature of the bovine placentome in the second half of gestation Journal of Anatomy 191 517-527

Lillie RD (1954) Histopathologic Technic and Practical Histochemistry The Blakiston Company, New York and Toronto

Lotthammer KH (1983) Vergleichende Untersuchungen über den Verlauf der Gehalte an Mineralstoffen, Stoffwechselmetaboliten, Enzymen und Hormonen bei Milchkühen mit und ohne spätere Retentio secundinarum Deutsche tierärztliche Wochenschrift 90 427-433

Margolis MJ, Williams WF, Davidson JP and Douglas LW (1983) Placental necrosis and giant cell numbers in relation to placental retention in cows Journal of Animal Science $\mathbf{5 7}$ Supplement $\mathbf{1} 355$

Maruyama R, Takemura G, Aoyama T et al. (2001) Dynamic process of apoptosis in adult rat cardiomyocytes analyzed using 48-hour videomicroscopy and electron microscopy American Journal of Pathology 159 683-691

Mayer P (1920) Zoomikrotechnik Bornträger, Berlin

Morgenstern E (1969) Vergleichende lichtoptische Untersuchungen im Rahmen elektronenmikroskopischer Arbeiten an ultradünnen Schnitten. II Färbemethoden Mikroskopie 25 250-260

Negoescu A, Lorimier P, Labat-Moleur F, Drouet C, Robert C, Guillermet C, Brambilla C and Brambilla E (1996) In situ apoptotic cell labelling by the TUNEL method: improvement and evaluation on cell preparations Journal of Histochemistry and Cytochemistry 44 959-968

Pfarrer C, Wirth C, Schuler G, Klisch K, Leiser R and Hoffmann B (1998) Relevance of proliferation and apoptosis for the placental development and the induction of parturition in the cow Journal of Veterinary Medicine, Series C 27433

Pfarrer C, Ebert B, Miglino MA, Klisch K and Leiser R (2000) The three-dimensional feto-maternal vascular interrelationship during early bovine placental development: a scanning electron microscopical study Journal of Anatomy 198 591-602

Prior RL and Laster DB (1979) Development of the bovine fetus Journal of Animal Science $\mathbf{4 8}$ 1546-1553

Reisinger L (1906) Über Kastration von Kühen Tierärztliches Zentralblatt 29 $86-90$
Reynolds ES (1963) The use of lead citrate at high $\mathrm{pH}$ as an electron-opaque stain in electron microscopy Journal of Cell Biology 17 208-212

Reynolds LP and Redmer DA (1995) Utero-placental vascular development and placental function Journal of Animal Science 73 1839-1851

Reynolds LP, Millaway DS, Kirsch JD, Infeld JE and Redmer DA (1990) Growth and in vitro metabolism of placental tissues of cows from day 100 to day 250 of gestation Journal of Reproduction and Fertility $\mathbf{8 9}$ 213-222

Richter J (1936) Der Einfluss der Kastration auf die Milch- und Fleischleistung der Kühe Berliner Tierärztliche Wochenschrift 49 277-280

Rudolf E, Peychl J and Cervinka M (2000) The dynamics of the hexavalent chromium induced apoptotic patterns in vitro. Acta Medica (Hradec Kralove) $\mathbf{4 3}$ 83-89

Rüsse I and Grunert E (1993) Das gravide Muttertier. In Tiergeburtshilfe pp 58-64 4th Edn. Eds E Grunert and K Arbeiter founded by J Richter and R Götze. Parey, Berlin

SAS (1999) StatView ${ }^{\circledR}$ Reference 3rd Edn, Statistical Analysis System Institute Inc., Cary, NC

Schnorr B and Kressin M (2001) Embryologie der Haustiere 4th Edn, Enke, Stuttgart

Schoon HA (1989) Lungen- und Plazentareifung beim Rind in der Endphase der Gravidität. Habilitation Thesis, School of Veterinary Medicine Hannover

Schuler G, Wirth C, Klisch K, Failing K and Hoffmann B (2000) Characterization of proliferative activity in bovine placentomes between day 150 and parturition by quantitative immunohistochemical detection of Ki67-antigen Reproduction in Domestic Animals 35 157-162

Schuler G, Wirth C, Teichmann U, Failing K, Leiser R, Thole H and Hoffmann B (2002) Occurrence of estrogen receptor alpha in bovine placentomes throughout mid- and late gestation and at parturition Biology of Reproduction 66 976-982

Schulz LC and Grunert E (1959) Physiologie und Pathologie der puerperalen Involution des Rinderuterus Deutsche tierärztliche Wochenschrift 66 29-37

Schulz LC and Merkt H (1956) Morphologische Befunde an extirpierten Plazentomen, zugleich ein Beitrag zur Ätiologie der Retentio secundinarum beim Rind Monatshefte für Veterinärmedizin 11 712-714

Shackney SE and Shankey TV (1999) Cell cycle models for molecular biology and molecular oncology: exploring new dimensions Cytometry $\mathbf{3 5}$ $97-116$

Shi SR, Cote RJ and Taylor CR (2001) Antigen retrieval techniques: current perspectives Journal of Histochemistry and Cytochemistry 49 931-937

Sobiraj A (1992) Untersuchungen zur Morphologie sowie zur Histochemie und Biochemie des Uterus bei Rindern in der frühen postpartalen Periode. Habilitation Thesis, University of Gießen

Stallmach T, Hebisch G, Meier K, Dudenhausen JW and Vogel M (2001) Rescue by birth: defective placental maturation and late fetal mortality Obstetrics and Gynecology 97 505-509

Stempak JG and Ward RT (1964) An improved staining method for electron microscopy Journal of Cell Biology 22 697-701

Takagi M, Fujimoto S, Ohtani M, Miyamoto A, Wijagunawardane MPB, Acosta TJ, Miyazawa K and Sato K (2002) Bovine retained placenta: hormonal concentrations in fetal and maternal placenta Placenta $\mathbf{2 3}$ 429-437

Verhaegen S (1998) Microscopical study of cell death via apoptosis European Microscopic Analysis 51 31-33

Walter I and Boos A (2001) Matrix metalloproteinases (MMP2 and MMP9) and tissue inhibitor of matrix metalloproteinases (TIMP-2) in the placental and interplacental uterine wall in normal cows and in cattle with retention of fetal membranes Placenta 22 473-487

Williams WF, Margolis MJ, Manspeaker J, Douglass LW and Davidson JP (1987) Peripartum changes in the bovine placenta related to fetal membrane retention Theriogenology 28 312-323

Willms N (1986) Untersuchungen zur spontanen und induzierten Plazentareifung beim Rind in der Endphase der Gravidität. PhD Thesis, School of Veterinary Medicine Hannover

Wischral A, Verreschi IT, Lima SB, Hayashi LF and Barnabe RC (2001) Preparturition profile of steroids and prostaglandin in cows with or without foetal membrane retention Animal Reproduction Science 67 181-188 
Woicke J, Schoon HA, Heuwieser W, Schulz LC and Grunert E (1986) Morphologische und funktionelle Aspekte plazentarer Reifungsmechanismen beim Rind. 1. Mitteilung: Lichtmikroskopische Befunde Zentralblatt für Veterinärmedizin Series A 33 660-667

Wooding FB, Hobbs T, Morgan G, Heap RB and Flint AP (1993) Cellular dynamics of growth in sheep and goat synepitheliochorial placentomes: an autoradiographic study Journal of Reproduction and Fertility 98275 283

Zerbe H, Hasseler W and Schuberth HJ (2002) Clinical, endocrinological and immunological investigations in the course of repeated lowdose Dexamethasone treatment inducing a premature parturition in cows Abstracts, XXII World Buiatrics Congress, August 18-23, (2002), Hanover, Germany, pp 93-94

Zhang WC, Nakao T, Moriyoshi MN, Nakada K, Ohtaki T, Ribadu AY and Tanaka Y (1999) The relationship between plasma oestrone sulphate concentrations in pregnant dairy cattle and calf birth weight, calf viability, placental weight and placental expulsion Animal Reproduction Science 54 169-178

Zheng J, Johnson ML, Redmer DA and Reynolds LP (1996) Estrogen and progesterone receptors, cell proliferation and c-fos expression in the ovine uterus during early pregnancy Endocrinology 137340 348

Received 30 January 2003.

First decision 12 March 2003.

Revised manuscript received 29 May 2003.

Accepted 29 May 2003. 